\title{
PENGARUH KOMPRES HANGAT GARAM KROSOK TERHADAP NYERI LUTUT PADA LANSIA DI KELURAHAN DARMO KECAMATAN WONOKROMO SURABAYA
}

\author{
Eny Astuti ${ }^{1}$ \\ ${ }^{1}$ STIKes William Booth Surabaya.Jl.Cimanuk No.20 Surabaya 60241 \\ Email : enyastutiserang@gmail.com
}

\begin{abstract}
ABSTRAK
Setiap orang, apalagi lansia (lanjut usia), tentu pernah merasakan nyeri selama perjalanan hidupnya. Perasaan nyeri ini kualitas dan kuantitasnya berbeda dari satu orang ke orang lain, tergantung dari tempat nyeri, waktu, penyebab dan lain-lain. Nyeri adalah sesuatu hal yang bersifat subjektif, tidak ada dua orang sekalipun yang mengalami kesamaan rasa nyeri. Beberapa terapi nonfarmakologi yang dapat diambil guna membantu mengurangi nyeri sendi pada lansia adalah kompres garam hangat. Penelitian ini bertujuan untuk mengetahui pengaruh kompres air garam hangat terhadap nyeri sendi pada lansia. Metode penelitian ini menggunakan dan menggunakan desain one group pretest-posttest. Variabel independen yaitu terapi dan one group pretestposttest. Jumlah sampel dalam penelitian ini adalah 13 responden dengan metode consecutive sampling. Analisis data pada penelitian ini menggunakan uji Wilcoxon. Sebelum dilakukan kompres garam hangat di dapatkan skala nyeri sedang 11 lansia $(84,6 \%)$ sedangkan sesudah dilakukan kompres garam hangat di dapatkan skala nyeri ringan 12 lansia $(92,3 \%)$ Hasil uji Wilcoxon menunjukan penurunan sebelum dan sesudah intervensi dengan nilai $\mathrm{p}=0,000$, sehingga ada pengaruh kompres hangat garam krosok terhadap nyeri lutut pada lansia di kelurahan Darmo Kecamatan Wonokromo Surabaya .Oleh karena itu penggunaan kompres hangat garam krosok dapat dipakai sebagai alternatif penanganan nyeri sendi pada lutut untuk lansia.
\end{abstract}

Kata Kunci: Kompres Hangat Garam, Nyeri Lutut, Lansia.

\section{ABSTRAC}

Everyone, especially the elderly (of the elderly), must have felt pain during the course of his life. This feeling of pain quality and quantity differ from one person to another, depending on the place of pain, time, causes and others. Pain is something that is subjective, not even two people experience the same pain. Some nonpharmacological therapies that can be taken to help reduce joint pain in the elderly are warm salt compresses. This study aims to determine the effect of warm salt water compresses on joint pain in the elderly. This research method uses quasy experiment and uses the design of one group pretest-posttest. The independent variable is quasy experiment therapy and one group pretest-posttest. The number of samples in this study were 13 respondents with consecutive sampling method. Data analysis in this study used the Wilcoxon test. Before the warm salt compress was carried out the moderate pain scale was 11 elderly (84.6\%) whereas after a warm salt compress was obtained a mild pain scale of 12 elderly (92.3\%) The Wilcoxon test results showed a decrease before and after intervention with a value of $p=0,000$, so that there is an effect of salt warm compresses against knee pain in the elderly in Darmo Village Wonokromo Surabay 
Subdistrict. Therefore the use of warm salt krosok compresses can be used as an alternative for treating knee joint pain for the elderly.

Keywords: Warm Salt Compress, Knee Pain, In the Elderly.

\section{PENDAHULUAN}

Menua atau menjadi tua adalah suatu keadaan yang terjadi dalam kehidupan manusia. Proses menua merupakan proses sepanjang hidup. tidak hanya dimulai dari satu waktu tertentu, tetapi dimulai sejak permulaan kehidupan.( Wahjudi Nugroho,2000). Proses penuaan akan menyebabkan perubahan anatomis, fisisologis, dan biokimia pada tubuh, sehingga akan mempengaruhi fungsi dan kemampuan tubuh secara keseluruhan. ( Depkes RI,2004). Perubahan-perubahan akan terjadi pada tubuh manusia sejalan dengan makin meningkatnya usia, yang terjadi sejak awal kehidupan hingga usia lanjut, pada semua organ dan jaringan tubuh. Keadaan demikian itu tampak pula pada sistem muskuloskeletal dan jaringan lain yang ada kaitannya dengan kemungkinan timbulnya nyeri sendi. Dimana hampir $8 \%$ orang-orang berusia 50 tahun ke atas mempunyai keluhan seperti adanya rasa nyeri pada sendi,pembengkakan panas dan gangguan saat melakukan aktivitas. Pola yang khas pada kelainan lutut ini dimulai dengan sendi - lutut kecil pada tangan, pergelangan tangan dan kaki. (Brunner dan Suddarth,2002). Nyeri sendi adalah suatu akibat yang diberikan tubuh karena pengapuran atau akibat penyakit lain.(Arif Muttaqin,2008). Nyeri lutut dianggap sebagai satu keadaan sebenar anya yang terdiri atas lebih dari 100 tipe kelainan yang berbeda. Nyeri sendi biasanya disebabkan oleh faktor penuaan. Sendi yang terkena umumnya lutut yang sering digunakan untuk bergerak dan sering mendapatkan beban. Menurut L.Tarau \& M. burst. 2011, Untuk mengatasi keluhan nyeri sendi tindakan yang dilakukan adalah istirahatkan sendi yang nyeri, menghindari keadaan basah dan udara dingin, kompres garam hangat, latihan peregangan, alat bantu ortopedik, terapi non medikamentosa konservatif seperti fisioterapi, terapi medikamentosa konservatif seperti pemberian analgesik, penyuntikan kortikosteroid intra-artikular, bentuk terapi topical seperti salep dan gel yang mengandung diklofenak atau ketoprofen dan terapi operatif. Berdasarkan pengalaman masyarakat di daerah flores khususnya di Kabupaten Manggarai menurut masyarakat di wilayah Manggarai Flores, jika timbul nyeri maka mereka melakukan kompres air garam dingin ,dan di pijat pake minyak GPU dan dilakukan 3 kali dalam seminggu dan hasilnya Nyeri lutut mulai berkurang. Sedangkan berdasarkan studi pendahuluan 10 Desember 2018.peneliti melakuan wawancara dengan sekelompok lanjut usia di RT 06 RW 07 di kelurahan Darmo kecamatan Wonokromo Surabaya. dan hasil wawancara terdapat banyak lanjut usia yang mengalami nyeri lutut ,Dan ada beberapa lanjut usia yang menyatakan bahwa nyeri ini timbul sering, kadang untuk mengurangi nyeri dengan kompres jahe hangat dan ada yang menggunakan kompres serai serta ada yang menggunakan obat analgesik,jamu yang beli di toko obat tanpa resep dokter misalnya paracitamol . Menurut (Darmojo .2011) dan saat ini terapi garam sudah ada yang mempergunakan dalam upaya menggurangi nyeri sendi pada lansia ,tetapi menggunakan air garam dan berhasil menurut hasil penelitian (D.E.Sari 2015) Berdasarkan apa yang penulis lihat di masyarakat manfaat dari air garam sering di gunakan untuk mandi menggurangi gatal gatal di seluruh badan, dan menghilangkan pegal di kaki ,mengurangi sakit gigi dan bau mulut, tetapi penulis belum menemukan garam krosok hangat untuk mengurangi nyeri lutut sehingga penulis tertarik untuk melakukan penelitian tentang "pengaruh garam krosok hangat terhadap penurunan nyeri lutut pada lansia "untuk mengetahui manfaat dari garam hangat tersebut . 
Di masa datang jumlah lansia di Indonesia semakin bertambah .pada tahun 1990 jumblah lansia 6,3\%(11,3 juta orang ),tahun 2006 menjadi 19 juta orang $(8,90 \%)$ dan usia harapan hidup juga meningkat (66,2 tahun )pada tahun 2010 penduduk lansia di Indonesia mencapai 23,9 juta atau $9,77 \%$ dan usia harapan hidup sekitar 67,4 tahun dan tahun 2015 jumlah lansia di perkirakan mencapai 24,5 juta orang.tahun 2020 jumlah lansia di indonesia di perkirakan akan menempati urutan ke -6 terbanyak di dunia dalam melebihi jumlah lansia lansia . Menurut WHO mendata penderita gangguan nyeri lutut di negara indonesia mencapai 81 $\%$,dari populasi,hanya $24 \%$ yang pergi ke dokter ,sedangkan $71 \%$ cendrung mengkonsumsi obat obatan peredaran nyeri yang di jualan bebas .angka ini menetapkan indonesia sebagai negara yang paling tinggi menderita gangguan nyeri lutut jika di bandinkan dengan negara asia lainnya secara umum pravelensi penyakit lutut di indonesian sangat tinggi sebesar 30,3\% pada usia 45-54 pravelensinya sebesar 46,3 \%usia 55-64 \%usia 65 -74 sebesar 62,2 \%usia lebih dari 75 sebesar 65,4 \%( badan penelitian dan pengembangan kesehatan ,depkes RI 2008 dalam bachtiar 2010) Bersasarkan hasil wawancara dengan kader lansia di wilayah Darmo Kali kecamatan wonokromo RT 7 RW 6 Penulis mendapatkan data terdapat sebanyak 40 orang lansia yang mengalami nyeri lutut ,tetapi ada 22 orang bisa beraktivitas mandiri dan yang mengalami Diabet sebanyak 10 orang, penyakit jantung 15 orang tetapi ada banyak beberapa lansia yang mengeluhkan nyeri lutut, namun tidak pernah di lakukan pemeriksaan oleh petugas kesehatan .

Menurut (L .Tarau dengan M .Burst .2011 ) penyebab utama nyeri lutut masih belum di ketahui secara pasti .biasanya merupakan kombinasi dari faktor genetic,lingkungan ,hormonal,dan faktor sistem reproduksi namun faktor pencetus terbesar adalah faktor infeksi,seperti bakteri,,mikroplasma,usia dan virus. (L .Tarau dengan M .Burst .2011) juga dalam bukunya menjelaskan bahwa manifestasi nyeri lutut dapat berfariasi diantaranya adalah nyeri lutut di pagi hari yang berlangsung singkat, nyeri yang timbul saat bergerak ,pembengkakan ,peradanggan ,kekakuan ,pembatasan gerakan .dampak dari keadaan ini dapat menimbulkan gangguan kenyamanan yang di sebabkan karena rasa nyeri yang di alami, dan apa bila nyeri tidak di tangani dengan baik akan menganggua aktivitas sehari hari di mana keadaan mudah lelah dsn terjadi keterbatasan mobilitas.akibat dai imobilitas adalah terjadi hal yang paling di takuti yaitu menimbulkan kecacatan seperti kelumpuhanan dan resiko tinggi terjadinya cedera hal hal di atas dapat membuat terjadinya perubahan citra diri karena tidak merasa tidak mampu untuk melakukan hal hal yang dapat di lakukan oleh orang- orang disekitarnya atau teman teman komunitasnya ,dari dampak di atas apa bila tidak di tangani dengan baik akan mengancam jiwa penderitaannya. (aqila smart ,2010 )berdasarkan penelitian yang di lakukan oleh indah lestari bahwa garam dapat di gunakan untuk mengguranggi nyeri lutut ,dan berfungsi menekan prostaglandin melalui hambatan pada aktifitas pada lutut manusia

Peran perawat dalam mengatasi nyeri Lutut pada lansia sangat penting yaitu dengan memberikan pendidikan kesehatan untuk mengurangi nyeri lutut. Upaya lain untuk mengatasi nyeri lutut pada lansia tersebut dapat dilakukan dengan tindakan non farmakologi seperti latihan fisik. dan menggunakan terapi garam hangat yang sederhana dan mudah dilakukan, Tujuan dari terapi garam hangat krosok ini yaitu mengurangi nyeri lutut dan dan menjaga kesehatan jasmani ,keuntungan lain dari terapi ini yaitu tulang menjadi lebih lentur ,otot tetap kencang,memperlancar peredaran darah dan kecepatan reaksi sel tubuh menjadi lebih baik (Heri 2014), Dan Pengobatan pada nyeri lutut ini bersifat multimodalitas dan melibatkan banyak di siplin ilmu yang di lakukan dengan tujuan untuk mencapaikan peredaan nyeri,mempertahankan mobilitas serta menghambat perkembangan penyakit dengan cara istirahatkan lutut yang nyeri, menghindari keadaan basah dan udara dingin, kompres garam hangat ,latihan 
peregangan ,alat bantu ortopedik ,terapi non medikamentosa konservatif seperti fisioterapi ,terapi medikamentosa konservatif seperti pemberian analgesik ,penyuntikan kortikosteroid ,intra artikular ,bentuk terapi topical seperti salep dan gel yang mengandung diklofenak adalah obat anti nyeri golongan OAINS atau ketoprofen adalah obat yang di gunakan untuk meredakan gejala seperti nyeri dan terapi operatif dari berbagai cara di atas penulis tertarik untuk melakukan penelitian dengan menggunakan terapi herbal yaitu garam krosok hangat .(L.Tarau dengan $M$ .Burst ,2011)

\section{METODE}

Rancangan penelitian yang digunakan dalam penelitian ini bersifat pra experimental ( one group pre-post test desigm). Kelompok subjek diobservasi sebelum dilakukan intervensi, kemudian di observasi lagi setelah dilakukan intervensi. Metode penelitian ini diajukan untuk menganalisis pengaruh tindakan kompres hangat garam krosok terhadap nyeri lutut pada lanjut usia. Pemberian intervensi ini akan dilakukan selama 3 kali dalam seminggu. Populasi dalam penelitian ini yaitu Seluruh Lansia yang mengalami nyeri lutut di kelurahan Darmo kecamatan wonokromo sebanyak 13 orang, kemudian ditentukan sampel sebanyak 13 orang. dengan menggunakan Total sampling yaitu seluruh Populasi diambil sebagai sampel penelitian. Sebelum melakukan penelitian, peneliti memberikan inform consent kepada Lansia dengan kriteria sampel bersedia untuk diteliti dan sesuai dengan kriteria sampel untuk penelitian. Instrumen pengambilan data dengan menggunakan Observasi. Untuk mengetahui pengaruh kompres hangat garam krosok terhadap nyeri Lutut pada Lansia di kelurahan Darmo Kecamatan Wonokromo Surabaya.

\section{HASIL PENELITIAN}

Hasil pengumpulan data tentang pengaruh kompres hangat garam krosok terhadap nyeri Lutut pada Lansia di kelurahan Darmo Kecamatan Wonokromo Surabaya. M pengaruh kompres hangat garam krosok terhadap nyeri Lutut pada Lansia di kelurahan Darmo Kecamatan Wonokromo Surabaya.

3.1 Karakteristik Responden Berdasarkan Jenis kelamin Responden

Tabel 3.1 Distribusi responden berdasarkan Jenis Kelamin

\begin{tabular}{cccc}
\hline No & Jenis Kelamin & f & \% \\
\hline 1 & Laki-laki & 0 & $0 \%$ \\
2 & Perempuan & 13 & $100 \%$ \\
\hline & total & 13 & $100 \%$ \\
\hline
\end{tabular}

Sumber Data : Kuesioner Penelitian

Berdasarkan tabel 3.1 dapat diketahui bahwa semua responden berjeis kelamin Perempuan $(100 \%)$

3.2 Karakteristik Responden berdasarkan Pendidikan

Tabe1 3.2 Karakteristik Responden Berdasarkan Umur

\begin{tabular}{cccc}
\hline No & Umur & f & \% \\
\hline 1 & 60-64 tahun & 2 & $15 \%$ \\
2 & 65-69 tahun & 2 & $15 \%$ \\
& $70-74$ tahun & 4 & $31 \%$ \\
3 & $75-79$ tahun & 3 & $24 \%$ \\
4 & $80-89$ tahun & 2 & $15 \%$ \\
\hline & Total & 13 & $100 \%$ \\
\hline
\end{tabular}

Sumber Data : Kuesioner Penelitian

Berdasarakan Tabe1 3.2 di atas menunjukkan bahwa terbanyak responden berumur 70-74 tahun yaitu sebanyak 4 responden $(31 \%)$.

\subsection{Karakteristik Responden berdasarkan} Paritas.

Tabe1:3.3 .Karakteristik Responden Berdasarkan Paritas.

\begin{tabular}{|c|c|c|c|}
\hline No & Pendidikan & $\mathbf{f}$ & $\%$ \\
\hline 1 & Tidak Sekolah & 1 & $8 \%$ \\
\hline 2 & SD & 7 & $52 \%$ \\
\hline 3 & SMP & 2 & $16 \%$ \\
\hline 4 & SMA & 2 & $16 \%$ \\
\hline 5 & Pendidikan Tinggi & 1 & $8 \%$ \\
\hline & Total & 13 & $100 \%$ \\
\hline
\end{tabular}

Sumber Data : Kuesioner Penelitian 
Berdasarkan tabel 3.3 dapat diketahui bahwa terbanyak responden berpendidikan $\mathrm{SD}$, yaitu sebanyak 7 responden $(52 \%)$.

3.4 Hasil Pengukuran Nyeri sebelum dilakukan Kompres hangat Garam Krosok.

Tabe1 3.4 Pengukuran Nyeri sebelum dilakukan kompres hangat garam krosok

\begin{tabular}{llcc}
\hline No & Pekerjaan & f & \% \\
\cline { 1 - 2 } 1 & Nyeri Ringan & 0 & $0 \%$ \\
2 & Nyeri Sedang & 11 & $85 \%$ \\
3 & Nyeri Berat & 2 & $15 \%$ \\
4 & Nyeri Hebat & 0 & $0 \%$ \\
\hline & Total & 13 & $100 \%$ \\
\hline
\end{tabular}

Sumber Data : Kuesioner Penelitian

Berdasarkan tabel 3.4 dapat diketahui bahwa sebagian besar responden mengalami Nyeri Sedang yaitu 11 responden (85\%), sebelum dilakukan Kompres Hangat Garam Krosok.

3.5 Hasil Pengukuran Nyeri sesudah dilakukan Kompres hangat Garam Krosok

Tabe1 3.5. Pengukuran Nyeri sesudah dilakukan kompres hangat garam krosok

\begin{tabular}{|c|c|c|c|}
\hline No & Status Perkawinan & $\mathbf{f}$ & $\%$ \\
\hline 1 & Nyeri Ringan & 12 & $92 \%$ \\
\hline 2 & Nyeri Sedang & 1 & $8 \%$ \\
\hline 3 & Nyeri Berat & 0 & $0 \%$ \\
\hline 4 & Nyeri Hebat & 0 & $0 \%$ \\
\hline & Total & 13 & $100 \%$ \\
\hline
\end{tabular}

Sumber Data : Kuesioner Penelitian

Berdasarkan tabel 3.5 dapat diketahui bahwa sebagian besar responden mengalami Nyeri Ringan yaitu 12 responden (92 \%), sesudah dilakukan Kompres Hangat Garam Krosok.

3.6 Pengaruh Kompres hangat Garam Krosok terhadap Nyeri Lutut Lansia.

Tabel 3.6 tabel tabulasi silang antara dukungan sosial keluarga dengan kecemasan nyeri sendi pada lansia di Posyandu Sedap Malam Krembangan Selatan Surabaya

\begin{tabular}{llll}
\hline No & Skala Nyeri & \multicolumn{2}{c}{ Penilaian } \\
& & Sebelum & sesudah \\
\hline 1. & Nyeri Ringan & $0(0 \%)$ & $12(92 \%)$ \\
2. & Nyeri Sedang & $11(85 \%)$ & $1(8 \%)$ \\
3 & Nyeri Berat & $2(15 \%)$ & 0 \\
4 & Nyeri Hebat & $0(0 \%)$ & 0 \\
\hline Jumlah & $13(100 \%)$ & $13(100 \%)$ \\
\hline \multicolumn{3}{l}{ Hasil Uji Statistik Wilcoxon : $\mathrm{p}=0,00$} \\
\hline
\end{tabular}

Berdasarkan tabel 5.6 dapat diketahui bahwa hasil penelitian di Kelurahan Darmo Kecamatan Wonokromo Surabaya sebelum dilakukan kompres Garam didapatkan sebagian besar responden yang mengalami nyeri sedang sebanyak 11 orang $(85 \%)$. Kemudian setelah dilakukan kompres Garam ditemukan responden yang mengalami nyeri ringan sebanyak 12 orang $(92 \%)$. Hasil analisa dari uji wilcoxon diketahui bahwa nilai $\mathrm{p}=0,00$ yaitu $\mathrm{p}<\alpha 0,05$ yang berarti Ho ditolak maka ada Pengaruh Kompres Hangat Garam Krosok Terhadap Nyeri Lutut pada Lansia Di Kelurahan Darmo Kecamatan Wonokromo Surabaya .

\section{PEMBAHASAN}

\subsection{Skala Nyeri Lutut Lansia sebelum Dilakukan Kompres Hangat Garam Krosok}

Berdasarkan tabel 3.4 responden yang mengalami nyeri sedang sebanyak 11 orang (85\%). Menurut Nugroho (2000) usia lanjut adalah tahap akhir dari siklus kehidupan manusia di dunia ini dimana pada tahap ini akan terjadi perubahan anatomi dan penurunan berbagai sistem fisiologis dalam tubuh manusia yang pada akhirnya akan mempengaruhi kemampuan tubuh untuk menjalankan aktivitas kehidupannya salah satunya adalah penurunan sistem musculoskeletal hal ini ditandai dengan adanya nyeri pada daerah persendian. sedangkan menurut Menurut Sri Surini P \& Budi Utomo (2003) pada 
saat memasuki lanjut usia cairan synovial pada tulang berkurang. Dimana cairan synovial ini berfungsi sebagai peredam kejut dan pelumas yang memungkinkan sendi untuk bergerak secara bebas dalam arah yang tepat Hal ini dapat dikaitkan dengan umur responden yang berdasarkan tabel 5.1 didapatkan bahwa banyak responden yang mengalami nyeri sendi berumur 70-74 tahun sebanyak 4 orang (31\%) dan umur 75-79 tahun sebanyak 3 orang (24\%). Dimana diketahui bahwa seiring dengan proses menua tersebut tubuh akan mengalami berbagai masalah kesehatan dimana pada lansia telah terjadi penurunan fungsi dari berbagai organ-organ tubuh akibat kerusakan sel-sel karena proses menua, sehingga produksi hormone, enzim, dan zat-zat yag diperlukan untuk kekebalan tubuh berkurang serta gaya hidup dari lansia itu sendiri sehingga menambah rasa sakit yang mereka alami serta pada lansia ambang nyeri meningkat mengakibatkan mereka akan lebih sensitive terhadap rasa sakit yang mereka alami. Hal inilah yang menyebabkan rasa nyeri itu timbul.

Berdasarkan fakta dan teori terdapat persamaan, hal ini terbukti dari hasil penelitian yang dilakukan menunjukan tingkat nyeri sedang secara teori terjadi penuruanan dalam tubuh khususnya pada lanjut usia selain itu juga dipengaruhi oleh respon masing masing individu dalam menerima nyeri tidak sama. Selain itu juga faktor psikologis juga bisa menjadi pengaruh tingkat nyeri seseorang.

Berdasarkan penelitian yang dilakukan dimana menunjukan bahwa seluruh responden yang mengalami nyeri sendi berjenis kelamin perempuan sebanyak 13 orang $(100 \%)$.

Menurut petti lubis (2009) prevelensi nyeri lutut lebih banyak terjadi pada wanita daripada laki-laki hal ini dikarenakan pengaruh hormone. Hormone yang dimaksud adalah adalah hormone estrogen dimana pada wanita hormone estrogen berperan untuk mengatur siklus menstruasi dan kehamilan serta salah satu fungsi dari hormone esrtrogen adalah mempertahankan massa tulang. Hormone estrogen ini dapat mempengaruhi zat kimia diotak yang berkaitan dengan nyeri . Dimana kadar hormone estrogen yang tinggi dapat membantu meringankan nyeri, sedangkan kadar hormone estrogen yang rendah dapat memperburuk rasa nyeri yang dialami.

Berdasarkan fakta dan teori maka terjadi persamaan, dimana pada seorang wanita yang sudah mengalami menoupase akan terjadinya penuruan hormone estrogen , fungsi hormone estrogen salah satunya untuk mengatur perkembangan seksual pada wanita, sehingga pada lanjut usia akan sering terjadi gangguan rasa nyaman nyeri, secara fisologis ini tidak masalah tetapi jika nyeri ini disebabkan oleh hal lain maka ini menjadi masalah dan harus dilakukan pengobatan .

Berdasarkan tingkat pendidikan pada lanjut usia yang terbanyak tingkat pendidikan Sekolah Dasar 7 orang ( $52 \%$ ). Menurut Mubarak dkk (2007) bahwa makin tinggi pendidikan seseorang makin mudah orang tersebut untuk menerima informasi dan akhirnya makin banyak pula pengetahuan yang dimilikinya dan dengan pendidikan tinggi maka seseorang akan cenderung untuk mendapatkan informasi baik dari orang lain maupun dari media massa. Hubungan ini tidak semata-mata diakibatkan karena perbedaan tingkat pendidikan tetapi tingkat pendidikan menjadi salah satu hal yang sangat berpengaruh terhadap bagaimana cara pencegahan dan pengobatan terhadap rasa sakit yang dialami.

Berdasrkan anatar fakta dan teori terdapat perbedaan , Pada hasil ini penelitian mayoritas tingkat pendidikan pada lanjut usia adalah sekolah dasar sehingga seseorang yang mempunyai tingkat pendidikan rendah akan sulit untuk mempersepsikan informasi yang diberiikan salah satunya dalam melakukan tindakan untuk mengurangi nyeri, meskipun demikian orang dengan pendidikan rendah bisa diajarkan secara langsung hal ini terbukti dari hasil penelitian lanjut usia bisa melakukan kompres garam hangat secara 
mandiri setelah dilakukan perlakuan oleh peneliti .

\subsection{Skala Nyeri Lutut Lansia Sesudah Dilakukan Kompres Hangat Garam Krosok}

Berdasarkan tabel 3.5 didapatkan bahwa responden yang mengalami nyeri ringan sebanyak 12 orang (92\%) Hasil tersebut menunjukan bahwa terjadi penurunan skala nyeri setelah dilakukan kompres Hangat. Garam Krosok Terhadap Penurunan Nyeri Lutut Pada Lansia. Menurut Katte Ferry - Swainson \& Eddy Soetrisno, (2004) kompres Hangat Garam Krosok Terhadap Penurunan Nyeri Lutut Pada Lansia Di Kelurahan Darmo Kecamatan Wonokromo Surabaya bermanfaat untuk mengurangi nyeri Lutut dikarenakan pada Garam mengandung ion dan mineral seperti ion natrium $(\mathrm{Na}$ + ), kalium (k+)magnesium ( $\mathrm{mg}++)$,kalium $(\mathrm{ca}++)$ Karbonat-bikarbonat (CO3 -Dan $\mathrm{HCO} 3$ 2-) Dan klorida (Cl-). ini semua sangat berperan penting dalam menjaga keseimbangan metabolisme tubuh Berdasarkan fakta dan teori ada persamaan dimana garam hangat mampu mengurangi nyeri apabila dilakukan sesuai dengan petunjuk yang dinstruksikan karena garamn hangat ini mempunyai fungsi memperlancar aliran darah dan membuat relaksasi otot sehingga membuat rasa nyeri yang dirasakan berkurang .Disisi lain juga dukungan dan kepercayaan dari pengurus lansia di kelurahan darmo , terhadap penyembuhan bagi anggota lansia kooperatif dengan tindakan terapi yang dilakukan peneliti.

\subsection{Pengaruh Kompres Hangat Garam krosok Terhadap Nyeri Lutut Pada Lansia di Kelurahan Darmo Kecamatan Wonokromo Surabaya}

Berdasarkan distribusi frekuensi pengukuran skala nyeri sebelum dan sesudah dilakukan kompres Garam tabel 5.8 dapat diketahui bahwa pasien yang mengalami nyeri Lutut sebelum kompres Garam didapatkan nyeri sedang sebanyak 11 orang $(85 \%)$ dan setelah dilakukan kompres Garam semua responden mengalami penurunan dimana nyeri ringan 12 orang (92\%) Berdasarkan hasil uji statistic WILCXON Pengaruh Kompres Hangat Garam Krosok Terhadap nyeri LututPada Lansia Di Kelurahan Darmo Kecamatan Wonokromo Surabaya diketahui bahwa nilai $p=0,00$ yaitu $p<0.05$ dengan demikian Ho ditolak yang memiliki arti ada Pengaruh Kompres Hangat GaramKrosok Terhadap Nyeri Lutut Pada Lansia di Kelurahan Darmo Kecamatan Wonokromo Surabaya.

Menurut Katte Ferry - Swainson \& Eddy Soetrisno, (2004) cara yang digunakan dalam kompres Garam Hangat adalah :Garam di masukan dalam Piring secukupnya. lalu masakan air di dandang sampai air mendidih Kemudian masukan saring dandang kemudian Masukan piring yang isi garam di panaskan selamanya 3-4 menit ,garam panas lalu masukan di kain yang bersih kemudian di kompres yang di lutut yang sakit . Efek farmakologi dari garam adalah sering haus, Tekanan Darah Tinggi, penyakit jantung, dan yang lebih lanjut garam ini ampuh untuk eksfoliasi kulit,hidung dan pembersih mata serta menyeimbangkan elektrolit di tubuh . ke otak, sehingga pintu ditutup dan tidak ada persepsi nyeri.

Hal ini terbukti dari hasil penelitian bahwa setelah dilakukan kompres Garam Hangat semua responden mengalami penurunan skala nyeri. Hal ini terjadi karena sifat dari garam itu sendiri yaitu rasa nyeri di bagian lutut berkurang serta tindakan pengkompresan dengan menggunakan Garam krosok hangat sehingga membantu untuk meningkatkan aliran darah. Hal ini juga tidak terlepas dari kemauan responden untuk mengurangi rasa sakit yang dialami dimana setiap pagi mereka rajin untuk melakukan olahraga.Serta tindakan pengkompresan yang dilakukan setiap hari dan sesuai prosedur yaitu sampai garam dingin lalu di ulanglagi dipanaskan. 


\section{KESIMPULAN}

Berdasarkan penelitian yang telah dilakukan maka dapat disimpulkan sebagai berikut :

1. Lansia yang berada di Posyandu Lansia Sedap Malam Krembangan Selatan Kelurahan Krembangan Selatan Surabaya sebagian besar memiliki dukungan sosial keluarga cukup.

2. Lansia yang berada di Posyandu Lansia Krembangan Selatan Surabaya kelurahan krembangan selatan kecamatan krembangan selatan Surabaya sebagian mengalami kecemasan ringan.

3. Terdapat hubungan antara dukungan sosial keluarga dengan kecemasan pada lansia yang berada di Posyandu Lansia Krembangan Selatan Surabaya kelurahan kecamatan krembangan selatan Surabaya.

\section{SARAN}

\section{Bagi STIKES William Booth}

Dengan adanya hasil penelitian ini diharapkan dapat dijadikan sebagai masukan dalam pembelajaran bagi mahasiswa untuk mata kuliah keperawatan dewasa sistem musculoskeletal sebagai salah satu terapi alternative lain dalam mengurangi nyeri Lutut .

\section{Bagi Tempat Penelitian}

Dengan adanya hasil penelitian ini diharapkan menambah wawasan dan pengalaman sehingga dapat melakukan tindakan kompres hangat menggunakan Garam krosok untuk membantu mengurangi Rasa Nyeri Lutut bagi para lansia yang berada di Kelurahan Darmo Kecamatan Wonokromo

\section{Bagi Peneliti Selanjutnya}

Diharapkan penelitian selanjutnya dapat menjadi sebagai acuan dan gambaran untuk mengembangkan kondisi yang sama dan sampel representatif.

\section{DAFTAR PUSTAKA}

Afroh,F.,Mohamad Judha,Sudarti, 2012. Teori Pengukuran Nyeri \& Nyeri Persalinan, Yogyakarta :NuhaMedika

Agus Mahendra, 2000. Senam. Jakarta: Dirjen Dikdasmen Depdiknas.

Ayu,A,D \&Warsito, B, E. 2012.Pemberian garam krosok hangat Pada Lansia Dengan Nyeri Lutut. Jurnal Nursing Studi. Hal 60-65. http://ejournals1.undip.ac.id/index.php/jnursing. Diperoleh18januari 2015

Brunner \& Suddarth. 2002. Buku Ajar Keperawatan Medikal Bedah. EGC : Jakarta

Claire, T. 2006. Yoga For Men. Penerjemah: Rahmani Astuti. Yogyakarta: B-First.

Corwin, J.E. 2001.Buku Saku Patofisiologi.Penerbit Buku Kedokteran. Jakarta: EGC.

Darmojo, Budi, \& Pratomo, h. 1999.Geriatri. Jakarta: FKUI

Guyton, A.C., dan Hall, J.E. 2008.Buku Ajar Fisiologi Kedokteran.Edisi 11. Jakarta: EGC

Hardywinoto. 2007. Panduan Gerontologi. Jakarta: Gramedia Pustaka Kabupaten Aceh Timur. pp. 23-31.

Heri, K. 2014. pengaruh kompres garam krosok hangata terhadap penurunan nyeri lutut pada lansia Jakarta Selatan. Jurnal Mahasiswa Program Keperawatan 
Universitas Esa Unggul, 1(1), h.1-10.

Henniwati. 2008.Faktor-faktor Yang Mempengaruhi Pemanfaatan Pelayana Posyandu Lanjut Usia Di Wilayah Kerja Puskesmas Kabupaten Aceh Timur. pp. 2331.

Kusmana, Pengaruh Kompres Air Garam Hngat Terhadap Nyeri Sendi Pada lansia (D.E.A.Sari , 2015) Jakarta

LeMone, P, Burke, Karen, 2008,Medical Surgical Nursing, Critical Thinking inClient Care(4thEdition), New Jersey: Prentice Hall Health.

Nugroho.W. 2000.Keperawatan Gerontik. Edisi 2. Jakarta. EGC.

Nurhidayah, K. 2012. Pengaruh kompres garam krosok hangat terhadap nyeri lutut pada lansia Banjarsari Surakarta, Muhammadiyah Surakarta, Solo (Skripsi), h.1-12.

Nursalam. 2011. Proses dan dokumentasi keperawatan, konsep dan praktek. Jakarta :Salemba Medika.

Nursalam. 2013. Metodologi penelitian: pendekatan praktis (edisi 3). Jakarta: Salemba Medika.

Nursalam. 2015. Manajemen Keperawatan. Jakarta: Salemba Medika.

Potter, P.A, Perry, A.G. 2005 Buku Ajar Fundamental Keperawatan :Konsep, Proses, dan Praktik. Edisi 4.Volume 2.Alih Bahasa :
Renata

Komalasari,dkk.Jakarta:EGC.

Priyatno. 2009. Farmakoterapi dan Terminologi Medis. Jabar: LESKONFI.

Rokim, 2009. Perubahan fisiologi pada Lansia dengan nyeri sendi, http://digilib.unimus. $a c$. id/files/disk1/146/ jtptunimusgdldiananggra-7263-3-babiipt.pdf). Diakses pada 11 januari 2016.

Salim, Emil, 1984, Perencanaan Pembangunan dan Pemerataan Pendapatan, Intildayu Press, Jakarta

Setiadi 2013. Konsepdan Praktek Penulisan Riset Keperawatan, Edisi 2. Yogyakarta, GrahaIlmu

Sindhu, Pujiastuti. 2006. Hidup Sehat dan Seimbang Dengan Yoga.Bandung :Qanita.

Somvir, Dr. 2006. Sehat Dengan Yoga dan Ayur weda. Paramita Surabaya

Stocklager, J. L, Schaeffer Liz. 2007. Buku Keperawatan Geriatrik. Dialih bahasakan oleh Nike Budhi Subekti. Edisi ke-2. Jakarta: EGC

Tamher,S.\&Noorkasiani. 2009. Kesehatan Usia Lanjut dengan Pendekatan Asuhan Keperawatan. Jakarta :Salemba Medika. Kabupaten Aceh Timur.pp. 23-31.

Tamsuri, 2017, Konsep Dan Penatalaksanaan Nyeri EGC, Jakarta

Weller S. 2011. Yoga Terapi. Jakarta : Raja Grafindo Persada. 